\title{
A TÉR KÉP EGY OLVASATA ÉS A, „TERÜLETI” TERVEZÉS
}

\section{(One Kind of Reading of the Space View and Spatial Planning)}

\section{FARAGÓ LÁSZLÓ}

Kulcsszavak:

tér hely régió regionalizació térhasznâlat térstruktúra területi, ágazati és rendezési tervezés regionális tudomány

A szerzö döntöen poszt-pozitivista nézöpontból körilírja a tér általános fogalmát és speciális kategoriáit, és tárgyalja ezek föbb jellemzöit. A térstruktúra kialakulásában döntö jelentöséget tulajdonit az emberi térhasználatnak. Jellemzi a kis- és nagyléptékü tereket, kitér a globalizáció néhány terïleti aspektusára, utal a regionalizáció sajátosságaira, és tárgyalja a térrel kapcsolatos fogalmak használatát. Mindezek bázisán a közösségi tervezés olyan eljárását írja le, amelyben megteremtödik a fejlesztési, a rendezési és az ágazati tervezés egysége. Összegzés helyett reagál a Nemes Nagy (2003) által felvetet kérdésekre, a területi tudomány dualitásával és paradigmájával kapcsolatban.

Hegel azt tanította, hogy az ember értelmi adottsága állandóan változik, annak a társadalomnak, nemzetnek a történeti fejlödése van rá hatással, amelyben él. E gondolatot Marx tovább vitte és bemutatta, hogy egy nemzeten belül is lehetnek eltérő ideológiákat képviseló osztályok, rétegek. Ma már állíthatjuk, hogy meghatározó eltérések lehetnek a területileg (kulturálisan) elkülönülő csoportok tudása, értékítélete között is, és ezek a különbségek jelentősebbek lehetnek, mint az osztályok vagy rétegek tudata közötti eltérések. Így a tervezésnek nemcsak hagyományos értelemben véve egyik dimenziója a tér, hanem a tervezésnek, mint új tudást és akaratot konstituáló folyamatnak is, mert az arra ható társadalmi-gazdasági feltételek meghatározott területi struktúrán belül termelódnek újra, a történetileg szituált cselekvéshelyzetek a konkrét térhez kötődnek, és a mindennapi élet szereplöi emberek, intézmények, gazdálkodó egységek stb. - függnek e területileg újratermelt viszonyoktól.

A térfelfogások történetileg is változnak. Foucault (2000) nagyobb történeti távlatban így mutatja be ezt a változást: A középkorban a helyek hierarchikus összessége létezett, a helyek szembenállása (szent és profán, városi és vidéki stb.) és keresztezödése alkotta a helymeghatározás terét. E zárt tér Galileinek köszönhetően kinyílt, és megszünt a középkori tér egyértelmüsége, a kiterjedés váltotta fel a helymeghatározást. „Mára a szerkezeti hely lépett a kiterjedés örökébe, amely a maga részéröl a helymeghatározás utódja volt. A szerkezeti helyet pontok vagy elemek közötti szomszédsági viszonyok határozzák meg, ezek pedig formálisan sorozatként, elágazásként vagy rácsozatként írhatók le. ... A korban, amelyben élünk, a tér a szerkezeti hely viszonyainak a formájában adódik számunkra." (Foucault 2000, 148) A szerkezeti helyek a vonatkozó viszonycsoportokból kiindulva írhatók le a legjobban. E viszonyokat még mindig a „süket szakralitással” átitatott ellentétpárok (pl. magán- és közszféra, kulturális és gazdasági tér) hatják át. 
„Jelenlegi korunk ... a tér korszaka lehet. Az egyidejüség, mellérendeltség, a közel és a távol, a jobbra és a balra, a szétszóródás korát éljük. Olyan pillanat ez, ... amelyben a világ nem annyira az időn keresztül kibontakozó életként, hanem pontokat összekötő és szálakat keresztezö hálóként tekint önmagára." (Foucault 2000, 147)

\section{Tér értelmezés}

A térbeli összefüggések vizsgálatának pozitivista megközelítési lehetősége egyre inkább visszaszorulóban van, és egyre nagyobb a transzcendentális fejtegetések létjogosultsága. Kvázi-objektív szemlélet csupán a geometria és a fizika meghatározott területein lehetséges, bár a geometria ugyancsak emberi gondolati konstrukció, amelynek tapasztalati forrása a szubjektív érzékiség.' Az euklideszi geometria axiómái is már csak korlátozottan érvényesek, ${ }^{2}$ és Heisenberg határozatlansági elve ${ }^{3}$ az egzakt mérésekbe vetett hitet is megrendítette. A pontosságra való törekvés nem csupán idö- és költség-korlátokba, hanem magába az anyag természetébe ütközik. ${ }^{4}$

Felvethetö, hogy az ilyen mélységekben rejlő bizalomvesztés a napi gyakorlat számára érdektelen, és a „területi tudomány(ok)ban” a teret kvázi-objektív fogódzóként kell értelmeznünk. Ezt látszik erősíteni, hogy minden imaginárius tér is a tapasztalatokon alapuló „valóságos” tér elemeiböl (távolság, pont, tér, térhierarchia stb.) épül fel, és magyarázataihoz is áltałában a geometriából és a földrajzi térből vett analógiákat használunk.

A gyakorlatban éppen ellenkező tapasztalataink is lehetnek. Például a társadalmi teret minél kisebb egységekre bontjuk, és minél közelebb jutunk az egyénhez, annál inkább a kognitív térnek, mint értelmezett társadalmi-gazdasági konstrukciónak, mint életvilágnak van jelentősége, és egyre kevésbé fontos a fizikai távolság, a térstruktúra objektivitása, és annál jobban nönek az értelmezésbeli különbségek és vele a bizonytalanság.

A tér általános fogalmának megértésében és tudatos használatában segít Kant magyarázatának átgondolása. „Minden jelenség, formáját tekintve, tér meg időben való szemléletet foglal magába, mely valamennyinek a priori alapul szolgál." (Kant 1981, 141) „A tér nem egyéb, mint a külsö érzékek minden jelenségének formája, azaz az érzékiség ama szubjektív föltétele, mely mellett egyedül lehetséges számunkra külső szemlélet." (Kant 1981, 52) Az érzékeléseink tárgyai a térben egymás mellett léteznek. „Állíthatjuk a tér empirikus realitását (minden lehető külső tapasztalatra vonatkozólag), de egyszersmind transzcendentális idealitását, azaz, hogy a tér semmi, mihelyt minden tapasztalat lehetségének föltételét elhagyjuk s olyasvalaminek tekintjük, ami maguknak a dolgoknak szolgál alapul. De nincs is a téren kívül más szubjektív, a külsőre vonatkoztatott képzetünk, mely a priori objektívnek volna nevezhetö. Mert egyikböl sem származtathatók le szintetikus a priori tételek, mint a térböl." (Kant 1981, 53) Tehát sajátos kettösség határozza meg térszemléletünket: a tér egyrészt a rajtunk kívüli tárgyaktól független tiszta szemlélet, gondolati konstrukció, másrészt minden létezö formája, kerete; egyrészt absztrakt (,szubjek- 
tív”) szemlélet, másrészt konkrét („objektív”) tapasztalati elemekböl álló gyakorlati konstrukció.

A tartalmak nélküli - csak elviekben létezỏ - tér egységes, egyforma „sürüségü” és üres, önmagában nem strukturálódik. Nem léteznek benne kitüntetett pontok, amelyek körül a jelenségek szükségszerủen szervezödnek vagy szervezhetők. Tehát csak az ember szemszögéböl beszélhetünk térszerkezetröl. A térstruktúrák részben a használatból következő viszonyrendszerből erednek, másrészt a térszemléletünk struktúrájának megfelelően alakulnak. A priori térszemléletünk történetileg változó, korábban meghatározóak voltak a tapasztalatainkhoz kötődő érzeteink, mára egyre inkább képesek vagyunk ettöl elvonatkoztatni. A mindennapi életben a térröl alkotott képünket leginkább az experimentális földrajzi tér és annak használata határozza meg, és ez az az elözetes tudás, amelyben a jelenségek térértel mezése interpretálódik, és amelyben, mint elöfeltételezésben a különböző térbeli összefüggéseket konstituáljuk, amelynek megfelelỏen cselekedeteinket térben szervezzük. Nem a tőlünk független tér strukturálja az emberi cselekedeteket, hanem mi emberek a tếrszemléletünknek megfelelöen alakuló térkapcsolatainkkal és azok objektivációival hozzuk létre a térstruktúrákat. ${ }^{5}$

Mindennapi létünk egyik dimenziója a tér, a másik pedig az idő. Minden változás (pl. mozgás) csak e két dimenzióban együttesen lehetséges. A tér-idö koordináták megadásával válik egy általános (egyetemes) állitäs konkréttá. Ha valamely létező vagy elképzelt dologhoz megadjuk területi koordinátáit, elhelyezzük a térben, azzal önmagán kiviulli többlettartalmat is adunk hozzá. Konkrét térben az elemek egymásra hatásának, azok kombinációjának más lesz a jelentősége, mint ha a tárgyi szféra elemeit önmagukban tekintenénk. ${ }^{6}$

A valóságban a tér sohasem üres és homogén. Az érzékelések tere a magánvaló világ tárgyain kívül tele van minőségekkel, értékekkel, utópiákkal, ítéletekkel, törekvésekkel stb. A tér mindezek együttlétezésének rendje, fizikai vagy virtuális kerete. A térbeliség a (fizikai) elkülönülés és egymásra hatás sajátos egységét adja. A különböző térhasználatok elkülönülnek (diszkrét jelleg) és a sajátos megközelítésnek megfelelöen elkülöníthetőek, ugyanakkor illeszkednek egymáshoz (horizontális kapcsolatok) vagy egymásba (vertikális kapcsolatok), azaz a tér folytonos, és így az együttlétezö elemei szükségképpen kölcsönhatásban vannak. A térhasználatok által elkülönüloó térelemeknek viszonylagos autonómiájuk van, és ezáltal versenyben, vagy akár konfliktusban lehetnek egymással vagy a természeti közegükkel, kívánatos esetben pedig harmonizálnak, kiegészítik egymást (kooperálnak), és a megfelelö közelségben (szomszédságban) vagy kapcsolatban (hálózatban) lévök mindenképpen hatnak egymásra.

Az együttlétezésböl következik a szükségszerü kölcsönhatás. Bármely térelem változása hatással van a többi térelemre is. Eo ipso megváltoztatja az öt befogadó tereket és hathat a horizontális struktúra más elemeire is. Például egy új gyártókapacitás létrehozása zavarhatja a szomszédokat, kihat a munkaerö-vonzáskörzetben lévő településekre és a világ bármely pontján hasonló terméket gyártók lehetőségeire. Általában igaz, hogy az egymásra hatás valószinüsége és erössége a fizikai és az 
idöbeli távolság növekedésével egyre kisebb. A technikai és technológiai forradalom (mobil távközlés, internet stb.), a globalizáció kapcsán egyre inkább szükségessé válik e tétel finomítása, kiegészítése. Például a globalizált tereken belül a távolság jelentősége csökken, míg az abból kimaradók relációjában nő.

Két, ugyanazokkal a minőségi és mennyiségi jellemzőkkel bíró tárgy ugyanazt a teret nem töltheti ki, így azonosak csak, mint a tiszta értelem tárgyai lehetnek. Ahogyan az idő egyes pillanatai nem cserélhetők fel, ugyanúgy nem cserélhetők fel a tér különbözö pontjai sem. A jelenségek, a cselekvéshelyzetek, a döntési helyzetek térben és időben meghatározottak és megismételhetetlenek. Ha ugyanazt máshol reprodukáljuk, akkor sem lesz azonos önmagával, mert ugyanannak a jelenségnek két meghatározó immanens sajátja, az időbeli és a térbeli koordinátái mások. Tehát geometriai és filozófiai értelemben is állíthatjuk, hogy a tér két különbözö eleme (pontja, egysége) nem lehet azonos egymással. Fizikai paramétereit tekintve, két azonos térelem szerkezeti helyzete, külső meghatározottsága eltéró. Társadalmigazdasági szempontból a különbözöség területi (helyi, regionális) sajátosságokban jelenik meg. Amikor a térbeli elemzések, modellek az időbeliségtöl eltekintenek, akkor hasonló hibába esnek, mint a térbeli dimenziótól való elvonatkoztatás esetén. Annál is inkább, mert a tér meghatározott eleme, látszólagos változatlanság ellenére sem azonos időbeni eltéréssel önmagával. ${ }^{7}$

A teret folytonos, de megszakított elemek sorozataként foghatjuk fel, amelyre nem az egymásutániság a jellemzö, hanem a megfagyott és széttört pillanat a magánvaló tárgyait, az embereket, cselekedeteiket, vágyaikat stb. eltérö területi pozíciókba és lehetséges funkciók sokaságába helyezi, amelyeket a térbeni viszonyrendszer köt össze, és teremt a megszakított elemek között különböző elrendeződéseket. E struktúrák létrejöttében a tudatosságnak és a beláthatatlanságnak (véletlennek) egyaránt szerepe van. A szabályszerüségeket mutató, ismétlődő elemek, események térstruktúrákat alkotnak, amelyeknek megkülönböztetett jelentőséget tulajdonítunk, fogalmakkal jelöljük, és esetenként materializáljuk is azokat.

A térbeli létezés nem csak, vagy nem egyszerủen az ember (társadalom) és a természeti-müvi környezet egymásra hatása. A jelenségek egyszerre játszódhatnak le a konkrét fizikai, földrajzi és egyéb összefüggéseket feltételező terekben, azaz konkrét és absztrakt terekben. Konkrét tér például a geometriai és a földrajzi tér, még az absztrakt terek az egzisztenciális és imaginárius terek összessége. Gyakrabban találkozunk az objektív és szubjektív terek megkülönböztetésével, de ez a felosztás azon az episztemológiai előfeltételezésen alapul, hogy a szubjektumtól függetlenül létezö magánvaló megismerhetô és leírható. ${ }^{8}$

A legszükebb konkrét térkategória a geometriai tér. Ennél bővebb a földrajzi és még tágabb az egzisztenciális terek köre. A természeti és művi környezet alkotja a földrajzi értelemben vett objektív - Perroux kifejezésével banális - teret. A szubjektív, de mégsem imaginárius terek (pl. társadalmi tér, mentális tér) egyre nagyobb jelentőségre tesznek szert, és egyre nő a tér e két kategóriája közötti különbség, az egybe-nem-esés. ${ }^{9}$ Ugyanakkor kétségtelen, hogy az absztrakt terek struktúráját is a legtöbb esetben a valóságos terek adják, illetve e struktúrák a különbözö megközelí- 
tések közös nevezői. A ,primitív” társadalmak esetében a különböző absztrakt terek többé-kevésbé egybeesnek és azonosíthatók a megtapasztalt földrajzi térrel. A fejlödés, a technikai haladás következtében a különbözö térstruktúrák egyre inkább tágulnak és még a földrajzi vetületük is elszakad a konkrét kisléptékủ terektől.

A területpolitika, a területfejlesztés szempontjából igen lényeges, hogy a társadalmi-gazdasági akciók integráló eleme a tér. Ahogy a tér integrálja a társadalmigazdasági eseményeket és sajátos viszonyt hoz létre a szereplők között, ugyanúgy a területi megközelítések (vizsgálatok, koncepciók, tervek stb.) is szükségszerủen interdiszciplinárisak és integratívak.

Alapvetően más kérdéseket vet fel a cyber-térben való gondolkodás és interveniálás, ahol az idỏtényezönek új dimenziói vannak, és a virtuális tér alakítása nem a hagyományos eszközökkel történik. A térröl kialakított általános (értelmezett) képünk alapján gondolkodunk a cyber-térben is, de konkréttá a programozói utasítások alapján a virtuális térben válik a gondolat. Az információs társadalom korában a tér sok - de nem minden - szempontból egy ponttá zsugorodik, és az elérhetőség ideje is a zéró felé tart. A virtuális világban nincs tél és nyár, nappal és éjszaka, mindegy, hogy városban élsz-e vagy falun, csak rá tudj kapcsolódni a hálóra. Ugyanakkor nem szabad megfeledkezni a virtuális és a valós világ kapcsolatáról. Hiába terjed sebesen az információ, hiába állnak rendelkezésre a világ minden pontján szinte egy időben az információk, ha azok kézzelfogható hatása, a megszerezhetỏ tudás hasznosítása ugyanazokba az akadályokba ütközik, mint korábban. Az elérhetöség térbeli terjedése nagyon hasonló más, hagyományos technikák terjedéséhez, és az internetes kapcsolatok létesítése is követi a centrum-periféria hierarchiát.

Úgy tủnhet, hogy a virtuális világban a hagyományos értelemben vett teret eltemethetjük, ${ }^{10}$ de napjainkban egyre bövül a térrel foglalkozó irodalom, és minden olyan tudományban is egyre többet foglalkoznak a térbeliségből következỏ sajátosságokkal, ahol korábban alig (közgazdaságtan és a különbözö társadalomtudományok).

\section{Az életvilág térstruktúráját meghatározó kis-és nagyléptékü terek}

A tér strukturalizálódása szempontjából meghatározó az emberi térhasználat és annak objektivációi. A sorozatosan elöforduló, ismétlődő térhasználatok gyakran tárgyiasulnak, a cselekvések, események a térstruktúra helyhez kötött elemévé válnak (lakóház, munkahely, város stb.). Az egymás mellett (térben) létező jelenségek térbeli viszonyaik, kapcsolataik alapján különbözỏ elrendeződéseket (rendezettség), térstruktúrákat alkotnak. A jelenségekben felismerhetök általánosítható területi szabályszerủségek, és meghatározhatók területileg eltérö különbségek is. A térhasználatban megmutatkozó alapvető eltérések alapján kis- és nagyléptékü tereket különböztethetünk meg $\mathrm{A}$ területi különbségek fizikai-földrajzi adottságokra és történetileg szituált kultúrspecifikus társadalmi különbségekre vezethetök vissza, amelyek jelentős egyenlőtlenségeket eredményeznek. Korunk legjellegzetesebb 
problémája a globalizáció és a lokális kultúrák közötti ellentmondás. Egyre inkább e viszonyrendszer válik meghatározóvá a korábbi centrum-periféria problematika mellett, helyett.

Alapvetöen a kisléptékü terekben újratermelödö tudáskészletéböl, konceptuális készletekből nyeri az egyén az ,értelmezéseit”, amikor nap mint nap kicseréli nézeteit a világ dolgairól és ezáltal újratermeli saját identitását. A cselekvő egyén , ,. terméke azon hagyományoknak, amelyekben benne áll, azon szolidaritási csoportoknak, amelyekhez tartozik, s azon szocializációs és tanulási folyamatoknak, amelyeknek alá van vetve. ... A kommunikatív mindennapi gyakorlat hálójává összeszövődő interakciók képezik azt a közeget, amelyen keresztül a kultúra, a társadalom és a személy újratermelödik." (Habermas 1986, 191-192) A kisléptékủ rendszerek (általában) informális önszervezódések és saját akarattal, „politikával” rendelkeznek, amelynek elsődleges referenciakerete a lokális értékrend. E terekben az „érzéki” és a szemtöl-szembeni kapcsolatok dominálnak, amelyeket a direkt személyes kapcsolatok határolnak be. Térszemléletünket alakító érzeteket is alapvetöen e kisléptékú terekben nyerjük. Az egyének, a kisebb közösségek minél inkább úgy érzik, hogy „elvesznek” az egyre növekvő, számukra átláthatatlan globalizálódó világban, annál inkább felismerik a mindennapi életterük jelentőségét.

Az egyén és a társadalom biztonságát a kisebb csoportokban, kisléptékủ terekben találhatja meg. Greenbie (1976) vizsgálatai alapján állítja, hogy az ember, mint társas lény - az állatokhoz hasonlóan - biztonságát térkapesolatainak középpontjában keresi. Az ember számára a társadalmi-területi szerveződések három fö típusa a legfontosabb: (1) az individuális tér, (2) az otthon és (3) a szomszédok, a barátok, a hobbi, a szolgáltatások, valamint a munkahely által meghatározott terület, amely a legtöbb esetben nem más, mint a település.

Ma már nem húzódhatunk vissza a kisléptékü terek biztonságába, elkerülhetetlen, hogy részesei legyünk olyan különféle kapcsolatokkal rendelkezö embercsoportoknak, amelyeknek más-más társadalmi, politikai határai vannak, és egyre növekvő a földrajzi kiterjedésük. A mindennapi életben cselekedeteink egyidejüleg zajlanak életterek, életvilágok sokaságában, különböző nagyléptékü térkategóriákban. A technikai haladás és a globalizáció objektív tendenciáinak következtében az árukon, a pénzen, a telekommunikáción keresztül mindenki kapcsolatba kerül egyre nagyobb és folyamatosan táguló terekkel.

A nagyléptékü területi kapcsolatok a közvetett kommunikáció segítségével túllépik a területileg-kulturálisan identifikálódott csoportok határait. A nagyléptékủ tér vertikálisan és funkcionálisan jól strukturált, tranzkulturális, és nagyfokú mobilitást tételez fel. A területfejlesztés szempontjából fontos, hogy minél nagyobb léptékü a müködtetett rendszer, annál inkább megkívánják a tevékenységek magas fokú szervezettségét, amelyet bürokratikus szervezetek, hatóságok irányítanak, nagy kiszolgáló apparátusok segítségével. 
Faragó László: A tér kép egy olvasata és a „területi” tervezés.

Tér és Társadalom, 17. 2003. 1. 19-40. p.

\section{TÁBLÁZAT \\ A kisléptékü és a nagyléptékü terek jellemzöi \\ (Characteristics of Small Scale and Large Scale Spaces)}

\begin{tabular}{lll}
\hline \multicolumn{1}{c}{ Kisléptékü terek } & - & Nagyléptékü terek \\
\hline lokalizáció & - & globalizáció \\
érzékek, érzelmek & - & érdekek, számítás \\
személyes és „,helyi” tudás & - & explicit tudás \\
helyi értékrend, tradíciók & - & „univerzális” értékek \\
személyes kommunikáció & - & közvetett bürokratikus kapcsolat \\
partnerség, horizontális kapcsolatok & - & vertikális hierarchia \\
területileg, kulturálisan meghatározott & - & transzkulturális (plurális) \\
területi identitás, helyi kötődés & - & mobilitás \\
informális önszerveződések & - & formalizált, strukturált \\
saját „politika” & - & szervezetek \\
stabilitás, szerves fejlődés & - & állandón változás, teljesítmény \\
& & orientáltság
\end{tabular}

Forrás: Saját szerkesztés.

Általánosságban megállapíthatjuk, hogy minél nagyobb léptékủ térről van szó, annál jobban eltávolodunk az első oszlop jellemzöitől, és annál igazabbá válnak a második oszlop állításai. Minél nagyobb léptékủ a térhasználat, annál globalizáltabb a rendszer, és annál általánosabb (annak tartott vagy feltüntetett) normák alapján múködik. Ha a globalizációt valóban egyetemes, kulturális relativizmustól független erkölcsi normák vezérlik, akkor nincs konfliktus a globális és a lokális kultúrák, térhasználatok között. Ma, sajnos erröl nem tudunk meggyöződni, és fennáll annak a veszélye, hogy nem a megértésen és az elfogadáson alapul a globalizációt vezérlő normák befogadása, hanem egyoldalú érdekérvényesítés során válnak „valakik lokális normái” metaelöírásokká. Arra kell törekednünk, hogy tendenciájában érvényesüljön az, hogy a magasabb területi szintek müködési elvei általánosabban elfogadott normákon nyugodjanak, de be kell látni, hogy minél nagyobb (átfogóbb) területi szintröl van szó, az érintettek köre annál nagyobb (meghatározott esetekben akár a föld teljes népessége), és annál nehezebb lefolytatni a normák elismertetéséhez szükséges nézetegyeztetéseket, diskurzusokat.

Egyre több olyan döntés születik az átlátható és befolyásolható kisléptékủ tereken kívül, amely hat a mindennapi életre. Minél nagyobb léptékủ térbeli rendszerekről van szó, annál kisebb az esély, hogy az egyén vagy helyi közösség (akár a kormányzat) hasson a döntésekre, részt vegyen azok kommunikatív megalapozásában. A globalizált nagyléptékü terekben a médiák hatalma, az új tőkeáramlási formák már-már veszélyeztetik a különbözỏ államok szuverenitását, stabilitását is. A meghatározó multinacionális cégek és számos világszervezet döntéseire alig vannak hatással a nemzetállamok kormányai (döntéshozói), a ráhatás inkább fordított. A 
társadalom egyre kisebb hányada tudja, hogy ki, hol és miért hozza az életterét és cselekvési lehetőségeit befolyásoló döntéseket. Az egyének, a kisebbségek, a hagyományos és az újabb kis közösségek szenvednek életterük kolonizálásától, a külső függöségtől. Részükröl egyre fokozódik az elégedetlenség a külső meghatározottsággal szemben, mindenki joggal akar részt venni az életterét érintö döntésekben, amelynek eszközét sokan az „,ideális vagy reális” kommunikációs közösségek müködtetésében látják.

A globalizáció nem fedi le az egész világot, és másként és különbözö ütemben terjed a gazdaságban, a társadalmi folyamatokban és a kultúrában. A globalizáció felfogható egy hatalmas hálózatként, amely összeköti, majd saját érdekeinek megfelelően megváltoztatja a világ különböző pontjait, településeket, régiókat, országokat, különbözö nemzeteket és kultúrákat. E folyamat alanyai sok tekintetben uniformalizálódnak, de egyben biztosan nem hasonlítanak egymásra, a haszonból és a hatalomból való részesedésben. A globalizáció belsỏ struktúrája hierarchikus hatalmi rend szerint épül fel. A folyamat nem érték- és érdeksemleges, nem egy önzetlen filantróp folyamat, még csak nem is multikulturális vagy plurális értékhordozó, addig és úgy terjed, amíg a mozgató érdekek érvényesülését szolgálják, a „Színesítések”, a területi adaptációk is a saját érdekérvényesítésük eszközei. A globalizáció során uniformalizálódott elemek mobilitási képessége és hajlandósága általában nagyobb, mint a szorosabb helyi-kulturális kötödéssel rendelkezöké. Ma a gazdasági fejlődés legjárhatóbb útja a globalizáció, ami kulturális westernizációval is jár, tehát ha az egyiket szükségböl elfogadjuk, akkor számolnunk kell a másik folyamattal is.

A globalizáció olyan, mint a képviseleti demokrácia, sok vele a gond, de ma úgy túnik, kimaradni belöle még több bajjal járna (,to be or to have a lunch”). A globalizáció folyamata számos paradoxonnal van tele. Például lehetővé válik a munkahelyek otthonokba vagy helyi munka-állomásokra költöztetése, így lehetöség kínálkozik a lakókörnyezetben, az életmódban meglévő számos sajátosság fenntartására. Ugyanakkor hiába tudunk minél több dolgot otthon, vagy a lakóhelyen elintézni, egyre többet utazunk és a kommunikációs eszközöket (telefon, fax, computer) is egyre gyakrabban vesszük igénybe. Elgondolkodtató, hogy a demokrácia és a szabad verseny biztosítása önmagában kevés a magas gazdasági teljesítmény eléréséhez, és ezek hiányában is müködhet a gazdaság hatékonyan.

A globalizációs hálózatok esetében is megvan az a kulturálisan meghatározott kisléptékü téregyüttes, amelyben gyökerezik, és föleg fejlödésének korai szakaszában energiáját kapja. A későbbiekben nő és terjeszkedik, esetenként leveleit (hálózati egységeket) vagy komplett ágait (területi hálózati szakasz, profil) ledobhatja, de ez is azt a célt szolgálja, hogy fennmaradjon, a gyökér és a törzs tovább erösödjön, hogy új erỏre kapva tovább bóvülhessen a hálózat, újabb területeket, embereket érjen el.

A globalizációval nem eltünik a területi-kulturális identitás, hanem - részben vagy egészében - más identitás lép a korábbi helyi gyökerü hovatartozás-tudat helyébe. $\mathrm{Az}$ uniformalizálódás kétségtelen negatív tényén túl nem biztos, hogy minden 
globalizációs trend ơnmagában káros. Ưgy gondolom, hogy például, amikor egy világhálózat alapvető higiéniás követelményeket honosít meg a világ elmaradottabb területein, az önmagában nem baj, de kétségtelen, hogy nem kéne mindenhol „letegezni" a fogyasztókat, és még többet kellene adaptálni a befogadó közegböl a globalizált (uniformalizált) egységnek is.

A kis- és nagyléptékü terek tovább strukturálódnak, pontosabban a térhasználatoknak megfelelően tovább strukturáljuk azokat. Az egymásba illeszkedő társadalomszerveződési tereket („életvilág struktúrákat”) a különböző megközelítések eredőjeként az alábbiakban foglalhatjuk össze:

személyes terek

- intim szféra

- otthon/háztartás

lokális terek

- szomszédság

- lakókörzet (településrész, kerület)

- település (helyi önkormányzat)

regionális terek

- kistérség/mikrokörzet (kistáj, városi vonzáskörzet)

- mezokörzet (gazdasági körzet, megye)

- nagytérség (régió, országrész)

makro-terek

$$
\begin{aligned}
& \text { - ország } \\
& \text { - ország-csoport } \\
& \text { - világ (föld) }
\end{aligned}
$$

A magasabb területi szint az alacsonyabb szinten lévő téregységeket szükségszerúen magába foglalja, ez a vertikális területi struktúra természetes formája. Minden téregység vizsgálható a részegységek aggregátumaként és mint szintetizált új tartalom. A nagyobb téregység a kisebb téregységekböl épül fel, és valamilyen többlettartalmat is hordoz. Kant 7+5=12 példáján (Kant 1981) jól szemléltethető az összefüggés. Sem a 7, sem az 5 képzetében nincs benne a 12. A 12 létrejöttéhez kell az is, hogy a kettő összetartozását, összeadását is hozzágondoljuk. Ezzel együtt kapunk egy szintetikus egyedi tételt. Egy adott téregységet vizsgálhatok, mint különféle jelenségek aggregátuma, szintézise (pl. a régió, mint a 12), és közelíthetem az egymás mellett létező folytonos alkotó elemek felöl is (mint az 5 és 7; azaz például a régiót alkotó megyék). De döntő, hogy mit gondolunk az összetartozásról, mi a magasabb területi szinten történő összegzés jellege!

A valóságos területi szintek átfogó entitások hierarchiáját alkotják. E rendszerben egymásra épülnek a struktúrát alkotó müködési elvek. ,... a hierarchia logikai szerkezetéböl következik, hogy egy magasabb szint csak olyan folyamat által jöhet létre, mely az alacsonyabb szinten nem nyilvánul meg, vagyis olyan folyamat által, amely ezért kiemelkedésnek (emergence) minősíthetö." (Polányi 1997, 200-201) 
„Egy szervezeten belül mindig a magasabb elv szabályozza a közvetlenül alatta levő elv által nyitva hagyott határt. Müködése során az alacsonyabb elvre támaszkodik, anélkül, hogy beleavatkozna annak törvényeibe, és mivel a magasabb elv logikailag nem magyarázható az alacsonyabb fogalmai által, az alacsonyabb szinten keresztül megvalósuló múködését időnként kudarc is kísérheti." (Polányi 1997, 204) ${ }^{11}$ A magasabb szintú területi funkciók mindig alacsonyabb szinten konkretizálódnak, de az alacsonyabb szintek csak abban az esetben, annak arányában járulnak hozzá, vesznek részt a megvalósításában, ha az egyben az ő saját céljaik elérését is szolgálja.

A magasabb szint létezése mindig a kevésbé átfogó alacsonyabb szintekben gyökerezik! Az alacsonyabb szintek a magasabb (összetettebb, bonyolultabb) szintek átfogóbb müködési elveinek keretein belül múködnek. Az alsóbb szintủ entitások autonóm szükségletei pedig behatárolják a felsőbb szintü entitás hatókörét. Tehát minden szint a saját, és a magukból alkotott magasabb szintek törvényszerüségei szerint müködik. A felsőbb szintek müködése nem magyarázható az alsóbb szinteket alkotó egységek müködése alapján, minden szintnek saját müködési elvei (törvényszerủségei) és funkciói vannak. A magasabb szintet saját müködési elvei szabályozzák, ugyanakkor nyitva hagyják az alsóbb szintek müködési tereit.

$\mathrm{Az}$ emberek megkülönböztetés, elkülönítés, a különböző viszonyok kezelése, irányítása érdekében, értékek és érdekek védelmére (mesterségesen) területeket határolnak le, falakat, kerítéseket emelnek, politikai, igazgatási határokat húznak. Ezzel megteremtik a belső-külső, a befogadás és kirekesztés kettősségét, a határsértés és a kritika lehetőségét. A határok az azonosulás és elutasítás mezsgyéi, amelyek két perspektívát és két legitimációs teret is létrehoznak. Ilyen demarkációra csak akkor van szükség, ha valamilyen célt szolgál a megkülönböztetés, az elkülönülés vagy elkülönítés, esetleg szükséges valamit másoktól, a kívülrekedtektöl megvédeni, vagy velük szemben érvényesíteni.

A területi határokat nem lehet pusztán pozitivista megközelítésben a térszerkezet elemzésével meghúzni, mintha azok a tér vagy a magánvaló dolgok természetéből erednének. Például a regionalizáció soha sem lehet formális öncél, csak folyamatok leképezése, szándékok kerete, eszköze. Az alapkérdés kétségtelenül az, hogy a régió eleve létező (vagy az adott fejlődési periódusban kialakuló) entitás, vagy csupán valamilyen célból létrehozott eszköz, strukturális egység. A régiók nem objektív fizikai térkategóriák, a regionális jelenségek nem egy általánosabb szubsztancia, a térbeliség eredöi, így nem szükségszerïen, mindenkor és mindenhol léteznek, hanem csak a tartalom felöl közelíthetó sajátos térszerkezeti egységek. A régióknak csak akkor van per se tartalmi vonatkozásuk, ha a zárt földrajzi egységben éló népességének olyan, a környezetétól különböző, sajátos és közös jellemzöi vannak (pl. nyelv, kultúra, történelmi tradíció, sajátos gazdaság), amelyeket szeretnének megőrizni és fejleszteni, azaz sajátos társadalmi-gazdasági folyamatok termelỏdnek újra ezen a szinten, és a közös értékek és érdekek a közös akarat és cselekvés alapját képezik. A legtöbb esetben, ettöl eltérően, a regionális térszerkezet, a területi 
intézmények többnyire csak hardwerként adnak formai kereteket bizonyos szoftwerek, funkciók, feladatok hatékonyabb, jobb ellátásához.

Alulról építkezó formális régióra csak akkor van szükség, ha léteznek olyan alsóbb szintü problémák, feladatok, amelyek az alacsonyab szinteken (hatékonyan) nem megoldhatók, azon túlnőnek, és azt be is látják, és nem indokolt a magasabb szintủ beavatkozás sem (szubszidiaritás elve). Ezek a mikro-, mezo- és makrorégiók (kistérségek, megyék, nagyrégiók) a közös belső értékek, érdekek védelmét szolgálják, és saját politika kialakítását és hatékony megvalósítását segíthetik. A formális régiók felülről való létrehozására és intézményesítésére (dekoncentrácio) elsősorban a központi feladatok hatékonyabb teljesítése érdekében lehet szükség. Mindkét érdek közös területi szinten való találkozása sajátos partnerséget eredményezhet, amely megjelenhet egy intézményen belül, ${ }^{12}$ és két különbözỏ típusú (DEKO, önkormányzat) intézmény együttmúködésében is.

Magyarország esetében jelenleg én hajlok a régió eszköz jellegének hangsúlyozása felé, de kétségtelen, hogy bizonyos folyamatok regionalizálása sajátos minöséget ad. Mivel az újabb határok és intézmények létrehozása csupán eszköz valamilyen cselekvés jobb ellátásához, ezért elözetesen (a folyamat jelenlegi állomásain) a mögöttes szándék mérlegelendő, és a regionalizációt az új intézmények valóságos müködése és a tényleges hatások ex post fogják minösíteni. Mint forma éppen úgy lehet a koncentráció, a dekoncentráció és a decentralizáció kerete. Számolni kell azzal is, hogy az új határok meghúzása, pl. az adminisztratív régiók létrehozása, esetünkben átrajzolja a térstruktúrát, új érdek- és diskurzustereket hoz létre.

\section{Fogalomhasználat}

Mind a mai napig sem a tudományos munkákban, sem a mindennapok gyakorlatában nem alakult ki egységes szóhasználat és a terminus technicusok használata nem elég tudatos.

Már az ókori görögök megkülönböztették a tér (chora) általános fogalmát a folyamatosan változó konkrét hely (topos, locus) fogalmától. A locus a tér általános fogalmánál szủkebb kategória, annak egy konkrét eleme. ${ }^{13} \mathrm{Az}$ általános és a konkrét sajátos relációját adja, hogy magának a tér-idő fogalmának megítélése is adott időhöz és helyhez köthetö, valamint az általános törvények, megállapítások a konkrét időben és helyen sajátosan érvényesülnek.

Az angol szaknyelvben az általánosabb fogalom a ,space” (tér), és a konkrét földrajzi helyet, területet jelölik a ,place" szóval. ${ }^{14} \mathrm{Az}$ európai uniós szóhasználatban a "regio" több közigazgatási alapegységet magában foglaló különböző nagyságú és közigazgatási státuszú téregységeket jelöl, még a „local” az államigazgatás helyi szintjére utal, amely sok országban több települést integrál. Így a ,regional"-t tulajdonképpen a „territorial” szakmai szinonimájaként területiként használják.

A magyar nyelvben a „tér”, a „térbeli” a nem-pontszerü jelölésére szolgál, és a "hely” megjelölés, annak egy jól körülhatárolható, tovább partikularizált pontjára, vagy egységként pontszerüen kezelt térelemére utal (telephely, település, üdülőhely, 
lerakóhely stb.). A területi tudomány(ok)ban a „területi” jelzőt általában a magasabb szintek, átfogóbb téregységek, a ,helyi”-t a vizsgálati szempontból alsó szint jelölésére használják, amely leggyakrabban a település, vagy az alsó közigazgatási szintet jelenti. ${ }^{15}$

Némi zavart okoz a régió megjelenése és a regionális jelző általános, területi értelemben vett használata. A mai szóhasználatban a régió megjelölést nem a helyi és a nemzeti szint közötti kisebb-nagyobb téregységek, a mikro-, mezo- és makrorégiók összefoglaló kategóriájaként használják, hanem csak a nemzeti szint alatti, több megyét érintő (magában foglaló) téregységekre, a nagyrégiókra. A „regionális” kifejezést viszont sok regionalista és tértudományokkal foglalkozó egyéb szakember nem erre a speciális térkategóriára vonatkoztatva (szükítve) használja, hanem az eredeti szélesebb, az „euroenglish"-nek is megfelelö értelemben, a „területi”' szinonimájaként, és így regionális politikáról, regionális tudományról stb. beszélnek. Ennek megfelelöen a területi gazdaságtan regionális gazdaságtanként, a területi tudomány regionális tudomány néven került be a köztudatba ${ }^{16}$ Ez a szóhasználat a kilencvenes évek második feléig nem okozott zavart, mert régiók hiányában az ilyen szintủ kérdések elkülönült megjelölésére nem volt szükség. Amennyiben a továbbiakban is a regionálist a terület szinonimájaként használják, akkor a zavar elkerülésére, a szükséges diszjunkció megtételére a régiópolitika, a régiótervezés, régiófejlesztési tanács stb. fogalmak használata kínálkozik, amelyek ma még idegenül hangzanak. Egyszerübb megoldás lenne a területi kifejezést használni általános értelemben, és meghagyni a regionális jelzöt a közbenső területi szintek jelölésére.

\section{A különbözö szempontok újraegyesítésének igénye és lehetösége}

A modern korban sajátos ellentmondást tapasztalhatunk a térröl való gondolkodásban, a folyamatok térbeni kezelésében és tervezésében. Annak ellenére, hogy már a felvilágosodás nagy gondolkodói (pl. Montesquieu, Voltaire) is felhívták a figyelmet arra, hogy az univerzális törvényszerüségek a térben konkretizálva sajátosan jelennek meg, mégis a különböző társadalomtudományok saját törvényszerüségeik megállapításainál igen gyakran eltekintettek a térbeliségtöl; a területi meghatározottságtól, és a közgondolkodás is sokáig olyan evidenciaként kezelte a teret, amivel nem is kell külön foglalkozni. A technika és a kommunikáció fejlödése következtében ez a jelenség még tovább erősödött. A „pontszerư” gondolkodásból eredö problémák (pl. centrum-periféria viszony, leszakadó, elmaradott területek) megoldása sok embert arra sarkallt, hogy kezdetben az elfogadott társadalomtudományok keretein belül térbeli szempontokkal egészítsék ki az általános megállapításokat (pl. regionális gazdaságtan); majd a különböző megközelítések közös elemeit szintetizálva és a térbeli összefüggéseket vizsgálva önálló axiómákat, tételeket alakítsanak ki, saját intézményeket (folyóiratok, tanszékek stb.) hozzanak létre, ami a területi tudomány(ok) megszületéséhez vezetett. A saját, önálló megközelítés (diszciplína) bizonyítása érdekében nem a társadalomtudományok által vizsgált tartalmak felöl közelítettek a valósághoz, hanem az azoktól függetlennek feltétele- 
zett teret tanulmányozták, határozták meg törvényszerüségeit, és azt vizsgálták, hogy ez a befogadó szerkezet milyen hatással van a megtöltő tartalmak egymás közötti viszonyaira (térszerkezet) és terjedésére. ${ }^{17} \mathrm{Ez}$ a folyamat sajátos, nem a lényegből következő bifurkációt eredményezett. A speciális tudományági megközelítésből fakadó tartalmi-szakmai jellemzőket és a dolgok, a jelenségek meghatározó sajátját, a térbeli jellemzőket egymástól elszakítva külön-külön vizsgálták. A tudomány(terület) fejlődése meghozta a tudományterület müvelőinek étvágyát, és többen a pozitív területi tudomány rangjának megszerzésén fáradoztak. Ennek érdekében visszatértek az empirizmushoz, és a módszertanon eluralkodott a matematikaistatisztika. Ezzel nem közelebb kerültek a valósághoz, hanem eltávolodtak a praxistól. Ennek következtében a konkrét helyen felmerülö gyakorlati problémákra nem lehetett kielégítő választ adni, így felértékelődött a különböző tudományterületek együttmüködésének, az inter- és multidiszciplináris megközelítéseknek a szükségessége.

Az integráció igénye, az együttmúködés szükségessége széles körben elfogadottá vált, de mind a mai napig nem tudatosult kellöképpen, hogy a tér (ideatórikus és konkrét struktúrák) szükségszerủen az együttgondolkodás, az együttműködés közös nevezője. A területi megközelités a praxisban mindig felértékelödik, mert az általános értékek partikularizálását és állításaink legitimácioját csak konkrét térben és idöben tudjuk elvégezni és minden cselekvés, beavatkozás is konkrét térben történik.

A közösségi tervezésben az idő dimenzión kívül a térnek van kitüntetett szerepe, így minden tervezés területi. Tehát a területi tervezés esetében a területi jelzövel való megkülönböztetést nem az teszi szükségessé, hogy a terv a tér egy adott elemére vonatkozik, a javasolt akciók konkrét térben valósulnak meg, hanem valami más. Egyrészt, akkor válhat szükségessé a területi jelző használata, amikor meg akarjuk kủlönböztetni az egyéb szempontokat preferáló, a térbeliséget csak másodlagosan kezelö tervektöl. Másrészt - és ez a fontosabb -, amikor konkrét téregységre vonatkozik (település, megye, régió, ország stb.), és a területileg elkülönülten élő, ahhoz kötődő (területi identitás) népesség (szubjektumok) tudása, normái és akarata adják a tervezés komplex referencia kereteit, és nem valamilyen parciális szakmai szempontrendszer. A decentralizáció, a szubszidiaritás, a partnerség is mind olyan társadalomszervezési és egyben tervezési alapelvek, amelyek a különböző társadalmi, gazdasági, diskurzus stb, terekhez kötődő tervezést erősítik.

Minden cselekvés konkrét térben és időben zajlik, így a tervkészítés során előbb vagy utóbb, meg kell adni a tér és időbeli koordinátákat. A tervezés során az általános ismeretekböl egyedi predikciókat vezetünk le. Minden partikularizált állítás azt jelenti, hogy az egyéb paraméterek mellett pontosan megnevezzük a helyet és időt. A hely megjelölés általában földrajzi térkategóriák megnevezését jelenti. Az egyedi megjelölések egyben valamilyen általánosabb térkategóriába (osztályokba, alosztályokba, területi szintekbe, településcsoportokba, térkategóriákba) való besorolást is jelentenek.

A hagyományos ágazatok ragaszkodnak a hatalmat jelentö önálló tervezéshez és a területi tervezés is folytatja harcát az integrációs szerep betöltése érdekében. Ez 
kezdetben a területi megközelítés sajátosságának a hangsúlyozását és önálló intézmények létrehozását jelenti, és ezzel párhuzamosan a tértudatos gondolkodás egyre inkább a funkcionális és ágazati tervezés részévé is válik. A fejlödés várhatóan új típusú társadalmi racionalizációs folyamathoz vezet, amelyben a tér újra minden jelenség formája, minden gondolat lehetséges kerete. Ehhez viszont az is kell, hogy a formát és tartalmat együtt kezeljük, a térszerkezetet, a térstruktúrát a tartalmak megjelenési, müködési formájának tekintsük.

Minden fejlesztési akciónak van egy adekvát térbeli dimenziója és a kor munkamegosztásának megfelelö mesterséges ágazati természete. E két tényező ugyanannak a dolognak két, egymástól elválaszthatatlan aspektusa. Ezzel szemben a fejlesztések többségének a meghatározásánál az ágazati szempontok dominálnak, amelyek nemcsak területi érdekeket sérthetnek, hanem a megvalósítás hatékonyságát is nagymértékben ronthatják. Az egyensúly helyreállítását nehezíti, hogy az ágazati szempontok érvényesítése mögött gyakran centralizációs érdekek is meghúzódnak, amelyek szembe kerülnek a területi elv érvényesítésével járó decentralizációval.

A területfejlesztési tervdokumentumok csaknem mindegyik javasolt beavatkozása (konkrét akció, intézkedés) valamely ágazathoz tartozik, és fordítva, az ágazati fejlesztések lokalizációja, területi beágyazódása fontos feladat, ezért kulcskérdés a területi és ágazati szakemberek együttmüködése. De az ágazati fejlesztések térbeni dimenziójának meghatározása, vagy a területi (regionális, megyei, kistérségi stb.) bontás/felosztás önmagában nem egyenló a területi szemlélet érvényre juttatásával.

\section{A fejlesztési, a rendezési és az ágazati tervezés egysége}

Magyarországon is évtizedeken keresztül a fizikai környezet alakítását, a területfelhasználás szabályozását, menedzselését szolgáló rendezési típusú tervezés uralta a területi tervezést. A hetvenes évek óta a müszaki szemléletü tervek fokozatosan kiegészülttek társadalmi, gazdasági szempontokkal, majd a rendezési tervek mellett megjelentek a különbözö téregységekre (pl. megye, kistérség) készülő társadalmi-gazdasági aspektusú fejlesztési koncepciók is. Ezeket a koncepciókat nem követte komplex fejlesztési tervek vagy programok készítése, hanem részben a pénzügyi és az ágazati tervek megvalósításán, másrészt rendezési tervek szabályozási funkcióján keresztül érvényesültek. A nyolcvanas évektől fokozatosan elkülönült egymástól a fejlesztési és a rendezési típusú tervezés, és a szükségszerü - és azóta folyamatosan napirenden lévő - integrálás mindmáig csak óhaj maradt. Ezen a helyzeten a törvényi és rendeleti - hiányos és zavaros - szabályozások sem segítettek. A két tervezési folyamat összehangolását személyes és csoportérdekeken kívül tervezéselméleti nézetkülönbségek is nehezítik. A rendezési és a fejlesztési tervezés más tervezéselméleti alapokon és módszereken nyugszik, eltérö paradigmák alapján dolgozik.

A rendezési tervezök alapvetỏen hosszú távú átfogó racionális tervezéselméleti alapokon állnak. A funkcionális racionalitást sajátosan értelmezik, a „szakmaiság és objektivitás" látszata érdekében értékválasztásaik forrásának a természeti-müvi 
környezetet állítják be. A szakmai fórumok és tervegyeztetések is többségében a „Szakmai szempontok” elfogadtatásának eszközei. A fejlesztési tervezök - részben az uniós integrációs elvárások okán - inkrementalista-stratégiai terveket készítenek. A fejlesztők a gyorsabb tanulási folyamatra teszik a hangsúlyt, terveiket középtávon megújítják. A fejlesztési tervezés elsősorban innovatív (esetleg radikális), így a változás kap nagyobb hangsúlyt, míg a rendezési tervezés ab ovo allokatív típusú, hosszú és nagytávlatokban gondolkodik, és a mủvi-környezeti értékek megőrzését kiemelt szempontként kezelí.

A rendezési tervezés alapvetöen természetfilozófiai (természetjogi) beállítottságú. Abból indul ki, hogy vannak az embereken kívülálló, azok életét meghatározó elvek, természeti törvényszerüségek, amelyekhez az emberi akaratnak igazodni kelI. A természetfilozófia laisser faire evolúciós elv alkalmazása szembeállítja az emberi akarat érvényesítését a természet törvényeivel. A természetjog naiv filozófiáján alapuló rendezési tervezés számos kritika tárgya:

- a „nem-beavatkozás” csak egy a lehetséges cselekedetek közül, amely nem a meglévő állapot megőrzését szolgálja, hanem az uralkodó trendek folytatódását;

- a kauzalitást - tévesen - összekeveri a teleológiával;

- a rendezési tervezỏ igen gyakran - önfelhatalmazás alapján - a természet médiumának szerepében lép fel;

- természeti törvényekre hivatkozva, gyakran objektív szükségszerüségként állítják be normatív javaslataikat;

- az empíria-közeli, a fizikai környezethez kapcsolódó állításokat a normatív megállapítások fölé helyezi;

- szakmai döntési körbe kívánják vonni a normatív értékválasztásokat.

- A rendezési tervezök által gyakran hangsúlyozott ökológiai elv nem végcél, hanem az eszközracionalitás során alkalmazható princípium.

A rendezési tervezés önmagában nem egy önálló tervezési ciklus, tanulásiellenőrzési kör, hanem egy egységes tervezési folyamat része. Ahhoz, hogy önálló közösségi tervezésként funkcionáljon, a tervezés két alapkérdésére „önállóan” kellene választ adnia. Maradéktalanul meg kellene felelnie a mit és a hogyan kérdésekre. A rendezési tervezés azt mondja meg, hogy a meglévő fizikai (természeti és müvi) keretek között, az érvényben lévő szabályok betartásával, a kívülrỏl kapott vagy a természeti törvényeknek tulajdonított célok megvalósítása milyen területfelhasználást eredményez, és milyen környezethasználati feltételeknek kell megfelelniük. Tehát nem posztulál önállóan új célokat, és a hogyanból csak a hol és miként kérdésre ad választ, de arra, hogy mikor, miből, ki által stb. már nem. Ugyanez fordítva is igaz, a rendezési vonatkozások nélkül a fejlesztési gondolkodás is hiányos lenne.

Mindebböl következően a fejlesztési és rendezési tervezés egy egységes tervezési folyamat része, amelyen belül megkülönböztetett alrendszer a területfelhasználás rendjének és a területhasználat szabályainak a meghatározása. Az egységes tervezés 
lehetöségét megalapozza, hogy a fejlesztési és a rendezési tervezésnek számos közös nevezője van:

- ugyanarra a fizikai környezetre ugyanaz az aktuális tudás vonatkozik;

- ugyanaz a társadalmi csoport adja a referenciakeretet: azonosak az értékek, normák és érdekek;

- azonos a cselekvéshelyzet, konkrét helyen és idöben ugyanazokat a célokat kell teljesíteni mindkettőnek.

Tételezzük fel - mint ahogyan azt a rendezési tervezök közül sokan állítják -, hogy a rendezési tervezés önálló tervezési folyamat, melynek során „saját” célokat kell kitüzni, amelyeket képes a „területrendezés” megvalósítani. Ez esetben ugyanolyan koncepcionális (normatív) döntéseket hoz, mint a fejlesztési tervezés. Tehát ez esetben nincs tervezésfilozófiailag különbség a rendezési tervezés és a fejlesztési tervezés között, így a kérdés az, hogy egymással párhuzamosan célszerü-e és szabad-e két vizsgálatot, koncepcionálási és döntési mechanizmust futtatni. Nyilván a cselekvéshelyzet azonos, és nem hozhatnak egymással ellentétes döntéseket ugyanarra az időszakra vonatkozóan, ugyanabban a térben/közösségben, ugyanazon a fórumon. Ez esetben nem lehet két különbözö tervezési mechanizmus, azaz a fejlesztési és rendezési tervezés egyazon területi tervezési folyamat munkafázisai. A tervezési folyamaton belüli elkülönítést az indokolja, hogy a területfelhasználás rendje és a területhasználat szabályai jogi ételemben is formális normává válnak, így e norma (rendelet, törvény) elókészítése, elfogadása és müködtetése megkülönböztetett eljárást tesz szükségessé, és meghatározott rendezési tervdokumentumok általános szabályozó jelentőségük miatt kiemelődnek a többi tervdokumentum közül. Tehát egységes településtervezésre, megyetervezésre, régiótervezésre stb. van szükség, amelyen belül különböző szabályokban jelennek meg a „,rendezési” vonatkozások.

Számomra mindebből az következik, hogy a fejlesztési és rendezési tervezésnek egységes helyzetfeltáráson kell alapulniuk és közös a koncepcionálás, a célmeghatározás, a stratégiaalkotás mozzanata is. Rendezési típusú gondolkodást (tervezést) igényel a kötöttségek, az elfogadott (vállalt) determinációk meghatározása, a fejlesztések ezeknek megfelelő szabályozása, és az elfogadott fejlesztési elhatározások területfelhasználásának müszaki megtervezése. A konkrét (ágazati, funkcionális, területi) programok (tervek) és akciók a stratégiai elhatározásoknak megfelelöen, a rendezési szabályokat és lehetőségeket figyelembe véve készülnek. Ezt a kívánatos folyamatot szemléltetem az 1. ábrán.

Az ábrán az első szaggatott vonal feletti rész- hagyományos terminológiával - a vizsgálati munkafázis. A két szaggatott vonal közötti területen történik az akarat explicitté tétele, új tudás létrehozása (szintetizálás, koncepcionálás, paradigmálás), melynek fontos részét képezi azoknak a szabályoknak a megalkotása és elfogadása, amelyek rendezési tervek formájában jelennek meg. A továbbiakban együtt vagy külön-külön tervezett (ágazati, funkcionális) programok, cselekvési tervek az egységes stratégiába illeszkedve az elfogadott rendezési szabályoknak megfelelően már a szakracionális szempontoknak megfelelöen funkcionális tervezési elvek alapján készülhetnek. Tehát az ágazati típusú (parciális) gondolkodás tipikusan a tervezésnek ebben a fázisában kap helyet. 
Faragó László: A tér kép egy olvasata és a „területi” tervezés.

Tér és Társadalom, 17. 2003. 1. 19-40. p.

\section{1. ÁBRA}

A rendezési és ágazati tervezés helye az egységes közösségi tervezés folyamatában

(The Location of Physical and Sectoral Planning in the Process of Single Community Planning)

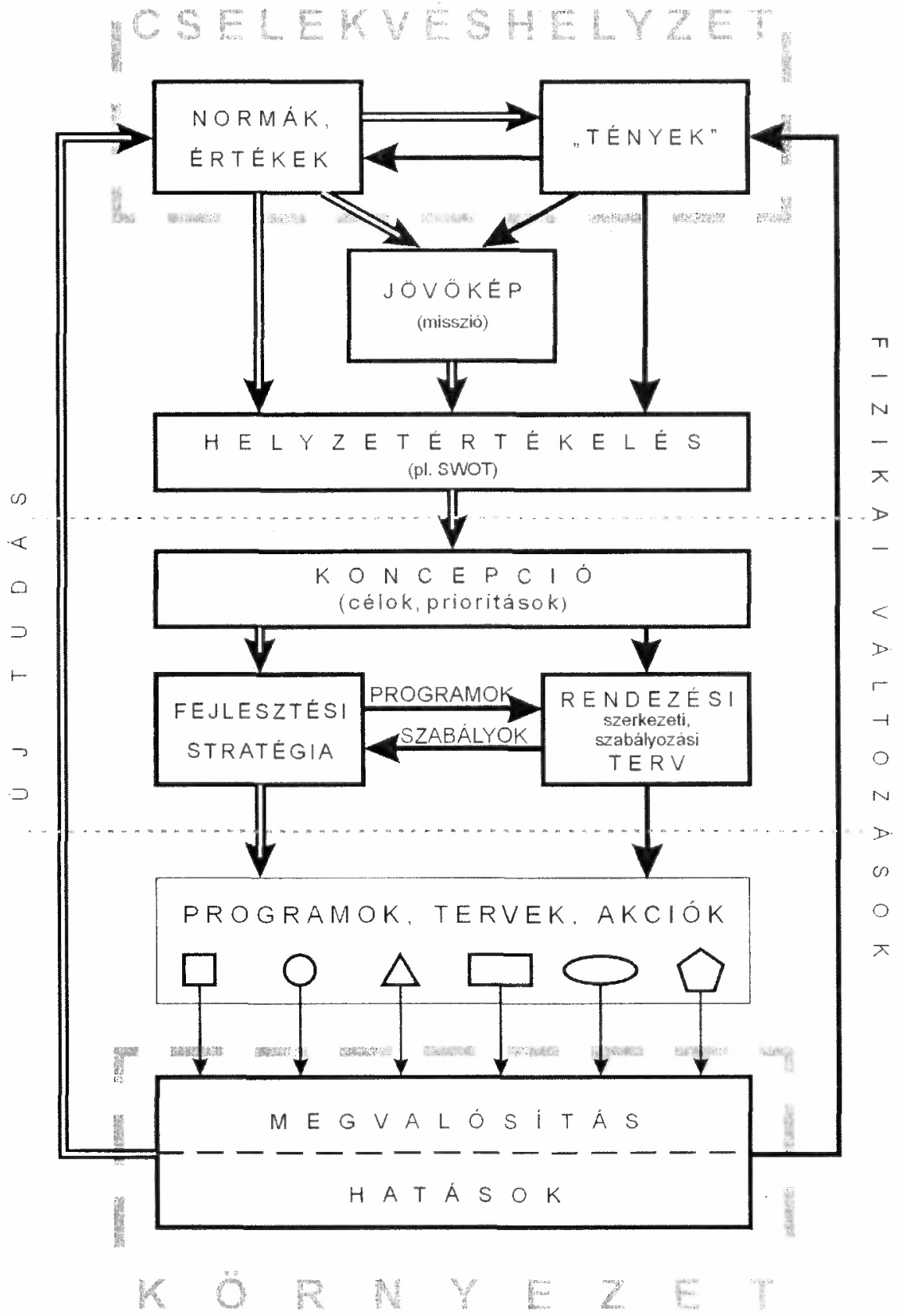

Forrás: Saját szerkesztés. 


\section{Összegzés helyett: paradigmaváltás a területi tudomány(ok)ban}

Nemes Nagy József ugyanebben a folyóiratszámban megjelenő, a regionális tudomány dualitásáról és paradigmáiról írt tanulmányát azzal fejezi be, hogy felkéri a témakör mủvelöit, nyilvánítsanak véleményt az általa felvetett kérdésekről, helyezzék el magukat gondolati rendszerében. Az eddigiekben leírtakból is kiolvasható számos azonosság és szemléleti különbség, de néhány általam problematikusnak tünő kérdéskörre külön is felhívom a figyelmet.

Nemes Nagy (2003) munkájában azt sugallja, hogy létezik a hagyományos tudományosság talaján álló, a reálfolyamatok elemzésére koncentráló térelmélet, amelyik ,a valóságos, s nem a kívánatos” kérdésekkel foglalkozik, és van egy másik vonal, amely inkább a gyakorlati politika kiszolgálója. Mondatai mögött ott érzem a természettudományoktól megkívánt objektivitásra, a hagyományos pozitivizmusra való törekvést, és annak magasabbrendüségébe vetett hitet.

Nincs mód arra, hogy a normatív társadalomtudományból kiragadjuk a térelméletet és az elemzés mozzanatát, és ezeket a valósághoz közelibbnek (igazabbnak) állítsuk be. Az elemzésnek nem „ellentétpárja” a tervezés, legfeljebb a szintézis. A tapasztalati adatokon nyugvó elemzések is az alkalmazott paradigma által meghatározottak, így normatívak és csak hipotézis értékủek. A megismerést is valamilyen érdek irányítja, a tényeket a szubjektumok hozzák létre! Ezért ebben a megközelítésben Nemes Nagy által felvázolt dualitás nem létezik. A deskriptív-normatív dualizmus feloldása éppen abban lehet, ha elfogadjuk, hogy minden tudás normatív. Értékválasztásokon nyugvó előzetes feltételezések nélküli elemzésnek se értelme, se lehetősége nincs. Az empirikus-analitikus megközelítés legfeljebb az önmegismerést és a jelenlegi helyzet fenntartását szolgálhatja, bármilyen terápia megadását kizárja. Egy tartalmaktól (minöségektöl, értékektől) megfosztott térelméletben még nincs benne a centrum-periféria viszony és más hasonló gyakorlati probléma, amelyik a térelmélet (területi tudomány) minőségét megadná. ${ }^{18}$

Szemléleti különbségek megvilágítása, osztályozási kísérlete véleményem szerint sikeresebb lehetett volna, ha valóban a paradigmák közötti különbségeket kutatja. A térbeli egyenlötlenség nem paradigma, hanem olyan axióma, amiben nincs nézetkülönbség, és a térelemek, a térszerkezet léte sem ,,paradigma erejü”. A különbségeket azokban a konceptuális készletekben lehet és kell keresni, amelyekkel a térelemek és a terïleti folyamatok megismeréséhez közelítünk, azokban az elkötelezettségekben, amelyek meghatározzák látásmódunkat, és abban, ahogyan kezeljük a különböző állítások érvényességét. Nincs paradigma értékü különbség abban, hogy „,a társadalmi tartalom mögé” kerül a térbeli szempont, vagy az üres tér ,töltődik meg társadalmi tartalommal". Mindkét megközelítésben az azonosság a meghatározó, az, hogy a teret, mint a tölünk függetlenül létezö fizikai befogadó szerkezetet tekinti. Más paradigmára épül például az általam felvázolt megközelítés, amelyik a tartalmak és azok viszonyrendszereinek aktív téralkotó szerepe felöl közelíti a térelemeket és a térszerkezetet. 
Nemes Nagy által érzékelt különbségek véleményem szerint javarészben a hatvanas, hetvenes években lezajlott pozitivizmus vita ${ }^{19}$ elvarratlan szálaiban gyökereznek, abban, hogy ki, milyen választ ad az elmélet és a gyakorlat, a „van és a legyen” közötti kapcsolat megteremtésére. Látszólag meg lehet kerülni a sikamlós értékválasztásokat, a politika közelségét, szemet lehet hunyni a megismerés nehézségei felett, és el lehet távolodni az absztrakció és a szük metodikai/módszertani kérdések irányába (1. pl. a „hivatalos” regionális tudományt a hatvanas évektöl egészen a nyolvanas évekig), de ez a törekvés szándékával ellentétben éppen a valóságtól való eltávolodást eredményezi. A legjobb eszközökkel és metodikákkal (szcientizmus) sem biztos, hogy elöbbre lehet jutni, mint a tudatosan felvállalt normatív megközelítéssel.

A területi tudomány(ok) paradigmaváltása kapcsán én nem a dualitásra, hanem a változások irányára teszem a hangsúlyt. Annál is inkább, mert a Nemes Nagy által is említett zavarosság éppen azt jelzi, hogy megindultak a változások, a paradigma néhány eleme kicserélödött, de nem történt még meg a váltás. A korábbi univerzális érvényességre igényt tartó magyarázat (metaparadigma) helyébe nem lépett még a kidolgozott új paradigmák sokasága. A változások irányát kitapintható hangsúlyeltolódások jelzik:

$\begin{array}{rll}\text { EMPIRISTA-ELEMZÖ } & - & \text { NORMATÍV, SZINTETIZÁLÓ } \\ \text { SZEMLÉLET } & \\ \text { abszolutista } & - & \text { relativista } \\ \text { objektív } & - & \text { szubjektív } \\ \text { objektív-szubjektív } & & \text { igaz-hamis } \\ \text { empirista } & - & \text { racionalista } \\ \text { pozitivizmus } & - & \text { poszt-pozitivizmus } \\ \text { strukturalizmus } & & \text { egzisztencializmus } \\ \text { metanarráció } & - & \text {,kis elbeszélések” sokasága } \\ \text { indukció } & - & \text { dedukció, } \\ \text { analízis } & - & \text { szintézis } \\ \text { deskriptív } & & \text { normatív } \\ \text { tapasztalat } & - & \text { önreflexió, jövőkép } \\ \text { mérhetỏ mennyiség } & & \text { minőség, érték } \\ \text { meggyőzés, érvényesítés } & & \text { kritika, érvelés } \\ \text { munka, teljesítmény } & & \text { diskurzus, megértés } \\ \text { igazolás } & & \text { érvényesség, legitimáció }\end{array}$

E felsorolás nem törekszik teljességre, inkább csak példaszerü, és a sorrendnek sincs jelentősége. Pragmatikus megközelítésemben ezek a fogalompárok nem feltétlen antinómiák, hanem létezik a kettő közötti tengely és az azon való választás lehetősége. Tehát nem arról van szó, hogy például választani kell az analízis és a szintézis között, hanem abban van a különbség, hogy ki melyiknek tulajdonít nagyobb jelentöséget és milyen kapcsolatot teremt a kettő között. A korábbiakban 
föként az első oszlopra támaszkodva állították össze a területi tudomány(ok) paradigmáját, konceptuális készletét, és inkább az empíriákhoz kötödve, a társadalmigazdasági környezet meghatározó, korlátozó feltételei között keresték a szükségszerünek vélt teendőket, és empirikus igazolásra törekedtek. Az újabb, alakulóban lévő paradigmákat a második oszlop irányába történő elmozdulás jellemzi. A változások hívei a szintézisre, az ember alkotó racionalitására teszik a hangsúlyt, a kívánatos jövő tükrében tekintenek a tényekre, és tévedési lehetőségük tudatában a tanulási folyamatnak tulajdonítanak nagyobb jelentőséget. Nem törekszenek állításaik univerzális érvényességére, azok érvényességét konkrét térben és idöben - többségében az ideális kommunikáció útján - keresik.

Többszörösen meghaladott zsákutcának érzek minden pozitivista térelmélet (területi tudományra) kialakítására irányuló törekvést, de mivel következetes akarok lenni a felvállalt prakticista, poszt-pozitivista (,posztmodern”) értékválasztásomhoz, ezért korlátozott alkalmazási lehetöségek mellett számolok a technikai megismerési érdek által irányított pozitivista paradigma létével.

\section{Jegyzetek}

1 „A geometria olyan tudomány, mely a tér tulajdonságait szintetikusan s mégis a priori határozza meg. ... a mi magyarázatunk teszi érthetóvé a geometriának, mint szintetikus a priori ismeretnek, a lehetségét." (Kant 1981, 51)

${ }^{2}$ Lásd a konstans görbületü, vagy a helyröl helyre változó görbülletủ nem-euklideszi geometriát.

${ }^{3}$ A megfigyelésen alapuló ellenörzés számára bizonyos fizikai események és mennyiségek örökre rejtve maradnak. Minden fizikai mérés során energiacsere történik, eżért olyan állapotról kapunk képet, ami már megsemmisúlt. Atomi objektumok esetében a mérés nem lehet a fizikában az egzakt elörejelzés alapja. A ,hely és impulzus” egyidejú mérése lehetetlen, e tekintetben tudásunk korlátozott.

4 Jean Perrin kimutatta, hogy a mérés pontosságának növelésévell nem csökken, hanem nó a bizonytalanság és az inkonzisztencia (Lyotard 1993, 121-122).

5 A ,pozitív térelméleteket" leginkább az asztrológiához tudom hasonlítani. Nem a csillagok állása van hatással az emberek természetére és cselekedeteire, hanem azłemberi léthez kapcsolódó megmagyarázhatatlan jelenségeket kötötték csillagképekhez, egy szemszögböl adódó látványhoz.

"Ugyanannak a fizikai valóságnak, pl. egy ,kozmopolita” Big-Mac szendvicsnek teljesen más a jelentése, ha egy New York-i szemetesben található, és más, ha Delhi belvárosában árulják. Egy csepp víz, abban a bizonyos pohárban túl sok is lehet, míg a sivatagban semmi.

${ }^{7}$ A tér-idö - egyen lötlenség és rendezettség témakörról lásd bỏvebben Nemes Nagy J. (1998).

${ }^{8}$ Nemes Nagy (1998) keveri az objektív és szubjektív térkategóriákat. Az objektív térkategóriába sorolja a nem anyagi (a szellemi) tereket is (68. o.). A fizikai környezet egyik elemét, az építészeti teret pedig mint a valóság mủvi elemét nem, hanem csak mint érzékszervi információt, az észlelt szubjektív teret tárgyalja (81-82. o.). Véleményem szerint például egy utópia is rendelkezhet leírható térszerkezettel, anélkül, hogy bármi valóságtartalma lenne, és az építészeti tér is éppen annyira tárgya az érzékszerveinknek, mint a rajtunk kívüiálló világ bármely más eleme.

${ }^{9}$ Episztemológiai értelemben ezek megismerhetösége egyre bonyolultabb és egyre kétségesebb.

10 A számítógépprogram segítségével is sajátos utakon juthatunk el konkrét helyre, amelyek között idóben, költségben, felhasználói szabadságban stb. eltérés lehet. Mindenkinek lehetnek kedvenc, gyakrabban látogatott "helyei" (web-lapjai), szokásos elérési útvonalai, amelyek a lényeges különbségek ellenére számos analógiát mutatnak a valós térhasználatokkal is.

11 Polányi Mihály ezeket a tételeket az élőlények evolúciójával és az individuum kifejlódésével kapcsolatban fejtette ki, de általánosságban érvényesnek tartom a hierarchizált entitásokra is.

${ }^{12}$ Erre irányuló kísérletnek tekintem a területfejlesztési tanácsokat. 
${ }^{13}$ Nemes Nagy másként írja le a tér és a hely relációját: .... a hely a legáltalánosabb térelem, a tér a helyek egyenlötlensége és rendezettsége" (1998, 86).

14 A ,plot" még tovább konkretizâlt tér-, földdarab.

${ }^{15}$ Megjegyzendö, hogy tếrelméletileg a magasabb területi szintek mindig magukban foglalják az alsóbb szinteket, így a „terủleti” jelzővel ellátott kategóriák szükségszerüen magukban foglalják az alsó telepuilési szintet is. Ettỏl eltér a gyakorlat, ahol a területi (,regionális") kategóriák mellé helyezik a települési szintet, mint attól független térkategóriát.

${ }^{16}$ Több új intézmény megalakulásakor is e gyakorlatot követték az elnevezésben: Regionális Kutatások Központja, MTA Regionális Tudományos Bizottsága stb. (Ezek a területi, regionális intézmények elnevezésükkel ellentétben foglalkoznak helyi, települési szintú, kistérségi ếs megyei kérdésekkel is.)

${ }^{17}$ Ha a regionális tudománynak (Regional Science) az a legföbb sajátja, amit Isard nyomán több követője állít, hogy a teret mint a tartalmaktól függetlenül létezöt vizsgálják, akkor az előzőekben írtak alapján állíthatjuk, hogy a vizsgálatuk tárgya a nem létezö üres és homogén tér. Mindebbỏl az adódik, hogy ebben a megközelitésben nincs regionális tudomány. Ezért szerencsésebb az anyatudományok területi kérdésekkel foglalkozó részterületeit területi (rész)tudományokként értelmezni, melyek közòs metszetét nevezhetjük a praxisban területi tudománynak (keresztdiszciplinaritás).

18 Popper (1976) szerint egy társadalomtudomány potenciális „teljesítménye” attól függ, hogy milyen problémát ragad meg. A megfigyelésnek is mindig konkrét problémára kell irányulnia.

19 Karl Popper, Theodor W. Adorno, Max Horkheimer, Jürgen Habermas stb.

\section{Irodalom}

Faragó L. (2001) Szeletek a tervezés mélyrétegeiból, - Tér és Társadalom. 3-4. 11-24. o.

Foucault, M. (2000) Nyelv a végtelenhez. Latin Betük, Debrecen.

Habermas, J. (1986) Magyarázatok a kommunikatív cselekvés fogalmához. - Magyar Filozófiai Szemle. 1-2. 175-200, o.

Greenbie, B. (1976) Design for Diversity. Elseiver, Amsterdam.

Kant, I. (1981) A tiszta ész kritikája. Akadémia Kiadó, Budapest. (Az 1913-as Franklin-társulat hasonmás kiadása.)

Kuhn, T.S. (1984) A tudományos forradalmak szerkezete. Gondolat, Budapest.

Lyotard, F. (1993) A posztmoder állapot. - Habermas, J.J.-Lyotard, F.-Rotry, R. A posztmodern állapot. Századvég Kiadó, Budapest. 7-145. o.

Myrdal, G. (1972) Érték a társadalomtudomänyban. Közgazdasági és Jogi Könyvkiadó, Budapest.

Nemes Nagy J. (1998) A tér a társadalomkutatásokban. Hilshcher Rezső Szociálpolitikai Egyesület, Budapest.

Nemes Nagy J. (2003) A regionális tudomány dualitása és paradigmái - hazai tükör. - Tér és Társadalom. 1. 1-17. o.

Papp Zs. (szerk.) (1976) Tény, érték, ideológia. Gondolat, Budapest.

Perroux, F. (1964) Economic Space: Theory and Applications. - Friedmann, J,-Alonso, W. (eds.) Regional Development and Planning. Tehe M. I. T. Press, Cambridge, Massachusetts. 21-36. o. Eredetileg publikálva: - Quaterly Journal of Economics. (1950) 2. február.

Polányi M. (1994) Személyes tudás. 1.--II. kötet. Atlantisz, Budapest.

Polányi M. (1997) Tudomány és ember. Három tanulmány. Argumentum Kiadó, Budapest.

Popper, K.R. (1976) A társadalomtudományok logikaja. - Papp Zs. (szerk.) Tény, érték, ideológia. Gondolat, Budapest. 279-301. o.

Popper, K.R. (1997) A tudományos kutatås logikaja. Európa Könyvkiadó, Budapest. 


\section{ONE KIND OF READING OF THE SPACE VIEW AND SPATIAL PLANNING}

\section{LÁSZLÓ FARAGÓ}

The author defines the general concept of space and its special categories from post positivistic view mainly and their principal characteristics. On the one hand the space is a clear aspect and a conceptual design existing independently from the objects outside of us, on the other hand it consists of shapes and frames of all of existing things. It is an abstract approach for one thing but then again it is an empirical construction consisting of concrete experimental elements. Space without contents is homogeneous, empty and it is not structured in itself. The space utilisation by humans is of crucial importance for the emergence of the spatial structure. The author characterises the two fundamentally different categories, the space with small scale and with large scale, touches on few spatial aspects of globalisation and refers to the theories of the emergence of the vertical spatial structure and to the features of regionalisation and discusses the Hungarian usage of the concepts which are connected with the concept of space and its problems. He finds that the formation of the regions in Hungary is not an objective necessity, but it is only a device. So the judgement on them is possible by considering the aim of their formation and its contents. On the basis of these, the author describes the method of integrated communal (spatial) planning in which the unity of the developmental, organisational, sector and functional planning is established. Instead of summary, he reacts on the questions in connection with duality and paradigm of territorial science of the article (by J. Nemes Nagy) published in the same issue. The author finds that the empirical and analytical approach (of positivism) is increasingly being changed by normative-synthesised approach (he describes its characteristics) although the new paradigms which are accepted by many people and exist side by side have not emerged yet. 